\title{
Simulation of Performance for 140 MW Thermal Power Station at Alkuraymat Using Solar Parabolic Trough Concentrators with Thermal Storage
}

\author{
A. M. Taiea ${ }^{1, *}$, M. M. Ibrahim ${ }^{1,2}$, K. F. Megalla ${ }^{1}$ and M. N. Metwally ${ }^{1}$ \\ ${ }^{1}$ Department of Mechanical Power Engineering, Faculty of Engineering at El- \\ Mataria, Helwan University, Massaken El-Helmia, P.O. 11718, Cairo, Egypt. \\ ${ }^{2}$ School of Energy, Power, and Mechanical Engineering, North China Electric \\ Power University, Beijing 102206, China.
}

\begin{abstract}
Solar power is a primary source of renewable energy and one of the most effective strategies for reducing emissions by reducing the consumption of fossil fuels. Alkuraymat power station produces about $140 \mathrm{MWe}$ divided into $120 \mathrm{MWe}$ produced from a combined cycle and $20 \mathrm{MWe}$ from a solar field with Therminol VP-1 as a heat transfer fluid. For environmental considerations, the present work aims to evaluate the design parameters and thermal performance of the Alkuraymat power plant operated with parabolic trough solar field with thermal energy storage simulated by using System Advisor Model (SAM) software. Alkuraymat location is suitable for using a concentrated solar thermal power plant due to receiving an annual direct normal irradiance of about $2,522.15 \mathrm{kWh} / \mathrm{m}^{2} /$ year. The results indicated that the concentrated solar thermal power plant consists of 514 solar collector loops, with each loop comprising of 4 parabolic trough collectors. As well, the proposed plant can produce annual electricity of $893.82 \mathrm{GWh}$ and the efficiency of the power plant is $19.4 \%$. Related to the optimization of the system configuration, the Levelized Cost of energy equal to $4.79 \mathrm{Cents} / \mathrm{kWh}$, and the full load hours of thermal energy storage reduces from 16 to $12.5 \mathrm{hrs}$. Additionally, the suggested design of the parabolic trough concentrated power plant and the study of its performance motivates further innovation and improvement of the solar thermal power plants in Egypt.
\end{abstract}

Keywords: Parabolic Trough Concentrator (PTC), Solar Power, Molten Salt, Energy Storage, System Advisor Model (SAM), Alkuraymat Power Station

\footnotetext{
*Corresponding Author ahmedm.abdo@m-eng.helwan.edu.eg
} 


\section{Nomenclature}

A $\quad$ area, $\mathrm{m}^{2}$

$\mathrm{C}_{\mathrm{p}} \quad$ specific heat, $\mathrm{kJ} / \mathrm{kg} . \mathrm{K}$

D diameter, $\mathrm{m}$

$\mathrm{F}_{1} \quad$ collector efficiency factor

$F_{R} \quad$ heat removal factor

$\mathrm{G}_{\mathrm{b}} \quad$ beam irradiance, $\mathrm{W} / \mathrm{m}^{2}$

$h \quad$ Convection heat transfer

$h \quad$ coefficient, $\mathrm{W} / \mathrm{m}^{2} \cdot \mathrm{K}$

$\mathrm{k}_{\theta} \quad$ incidence angle modifier

$\mathrm{K}$ thermal conductivity

K coefficient, $\mathrm{W} / \mathrm{m} \cdot \mathrm{K}$

$\mathrm{L} \quad$ length, $\mathrm{m}$

$\dot{m}$ mass flow rate, $\mathrm{kg} / \mathrm{s}$

M mass, $\mathrm{kg}$

$\mathrm{Nu} \quad$ Nusselt number

Pr Prandtl number

$\dot{Q} \quad$ heat rate, $\mathrm{kW}$

Re Reynolds number

$s$

$\mathrm{S}$ absorbed radiation, $\mathrm{W} / \mathrm{m}^{2}$

$\mathrm{T}$ temperature, $\mathrm{K}$

$U$ heat loss coefficient, $\mathrm{W} / \mathrm{m}^{2} \cdot \mathrm{K}$

$W \quad$ width, $\mathrm{m}$

\section{Greek symbols}

$\alpha \quad$ the receiver absorption

$\delta \quad$ angle of declination, ${ }^{\circ}$

$\varepsilon$ the factor emittance

$\eta \quad$ efficiency, $\%$

$\omega \quad$ hour angle, ${ }^{\circ}$

$\theta \quad$ angle of incidence, ${ }^{\circ}$

$\theta_{\mathrm{z}} \quad$ zenith angle, ${ }^{\circ}$

$\sigma \quad$ Stefan Boltzmann constant, $\mathrm{kW} / \mathrm{m}^{2} \cdot \mathrm{K}^{4}$

$\varrho \quad$ factor of reflectance

$\rho \quad$ Density, $\mathrm{kg} / \mathrm{m}^{3}$

$\tau$ transmittance factor

$\gamma \quad$ intercept factor

\section{Subscripts}

0 ambient condition

a air

ap aperture

av average

c cover

o outlet

$r \quad$ receiver

$\mathrm{Pb} \quad$ power block

Sf $\quad$ Solar filed 


\begin{tabular}{|c|c|c|c|}
\hline \multicolumn{4}{|c|}{ Acronyms } \\
\hline NREL & $\begin{array}{l}\text { National Renewable Energy } \\
\text { Laboratory }\end{array}$ & $\mathrm{LCOE}$ & $\begin{array}{l}\text { Levelized cost of } \\
\text { energy }\end{array}$ \\
\hline CSP & Concentrated solar power & PTC & $\begin{array}{l}\text { Parabolic trough } \\
\text { concentrator }\end{array}$ \\
\hline DNI & Direct normal irradiance & PTSC & $\begin{array}{l}\text { Parabolic trough solar } \\
\text { collector }\end{array}$ \\
\hline FBS & fuel backup system & SAM & Solar advisory model \\
\hline HTF & Heat transfer fluid & TES & $\begin{array}{l}\text { Thermal energy } \\
\text { storage }\end{array}$ \\
\hline ISCC & $\begin{array}{l}\text { integrated solar combined } \\
\text { cycle }\end{array}$ & TMY & $\begin{array}{l}\text { Typical } \\
\text { Meteorological Year }\end{array}$ \\
\hline
\end{tabular}

\section{Introduction}

Solar power generation is one of the most effective strategies for reducing emissions by decreasing the consumption of fossil fuels. There is an important integrated solar combined cycle (ISCC) power station in Egypt, installed at Alkuraymat (south of Cairo), which is in operation since 2012, with a total power of $140 \mathrm{MWe}$. Alkuraymat power plant uses Therminol VP-1 as heat transfer fluid (HTF) in the solar field to produce super-heated water steam via steam generator, which assists the plant with additional $20 \mathrm{MWe}$, while $120 \mathrm{MWe}$ is produced using natural gas as base fuel in the power block [1].

Awan and Zubair [2] are compare the parabolic trough CSP and photovoltaic plants at three different sites in Saudi Arabia related to techno-economic basis point of view. The electrical performance, solar to electric efficiency, land use factor and capacity factor are used to compare the two types of technologies. The economic comparison is done using net capital cost, net present value, LCOE, and payback duration. Also, Bilal Awan et al. [3] covered the present and future status of PTC plants, as well as technical developments in various components of commercial CSP plants based on PTC technology. There is a summary of 100 PTC plants worldwide that are currently operating, under construction, or in the planning stage.

In Algeria, Eeddine Boukelia and Mecibah [4], studied the construction of parabolic trough solar thermal power plants and the operation principles of CSP plants have been established, as well as an evaluation of Algeria's concentrated solar energy capacity. The analysis demonstrates CSP plants' competitive feasibility.

Boukelia et al. [5] optimized, selected, and conducted a feasibility analysis for solar parabolic trough power plants in Algeria. Two CSP plants with fuel backup systems (FBS) and thermal energy storage (TES) have been optimized. The heat transfer fluid used for the first and second plants was Therminol VP-1 and molten salt, respectively. 
A simulation model was developed by García et al. [6] which would recalculate the performance of a $50 \mathrm{MWe}$ CSP station with energy storage and the use of Therminol VP-1 as an HTF. The model's performance is validated by experimental data from a power plant in Spanish.

Montes et al. [7] investigated the impact of the solar multiple on energy costs, yearly growth, and natural gas consumption for a $50 \mathrm{MW}$ direct steam production. The plant has a thermal energy storage facility as well as a natural gas-fired auxiliary boiler.

A thermodynamic model has been developed by Larraín et al. [8] to predicate the efficiency of a hybrid solar thermal plant with a capacity of 100 MWe and the amount of fossil-fuel backup required. The thermodynamic model was used to select the lowest possible fossil fuel backup fraction at four locations in northern Chile.

A solar thermal power plant with a $50 \mathrm{MW}$ capacity was investigated by Kalogirou [9] in Cyprus, analyzing its technical performance, energy costs, and necessary land area. The parabolic trough system was proposed as the best technology due to its industrial sophistication and advantages.

Abbas et al. [10] investigated the energetic economics of a $100 \mathrm{MW}$ solar parabolic trough power plant for four typical Algerian locations. Ruegamer et al. [11] discussed the technical advances of parabolic through solar power plants using molten salt as the heat transfer fluid (HTF) and the potential for lowering the Levelized cost of energy (LCOE) through the use of this technology. A feasibility study is also performed in the solar sector, incorporating optimization and 4E comparison of PTSTPPs with molten salt as the primary HTF. Xu et al [12] reached a similar conclusion.

Reddy et al. [13] investigated energetic and exergetic analysis under a variety of operating conditions in order to improve the plant's performance. According to the above literature review, there has been no study of the technological viability of PTSTPP in a place with high DNI availability. Additionally, no optimal CSP technology has been established for Egypt's climatic conditions. The aim of this research is to address a knowledge gap in the field of solar thermal systems.

The major objective of the present work is to achieve a new design for the Alkuraymat power plant operated with $100 \%$ solar energy using PTC field, with additional thermal energy storage tanks using molten salt as HTF through the main solar PTC field of collection. The Simulation and analysis of the proposed CSP parabolic trough technology from thermodynamic aspects and annual output by using SAM software.

\section{System description}

As seen in figure 1, the CSP plant model is divided into three subsystems: (i) the solar field, (ii) the thermal storage device, and (iii) the power block. The solar field is made up of parabolic trough solar collectors that direct sunlight from the sun to cylindrical receivers. The thermal power is transferred from the solar field to the power block by the heat transfer fluid which is passing through the receiver. After transfer the thermal power to a Rankine cycle power block that is used to generate energy by a turbine 
and coupled generator. a two-tank system is used for the thermal energy storage system, with molten salt as a storage medium.

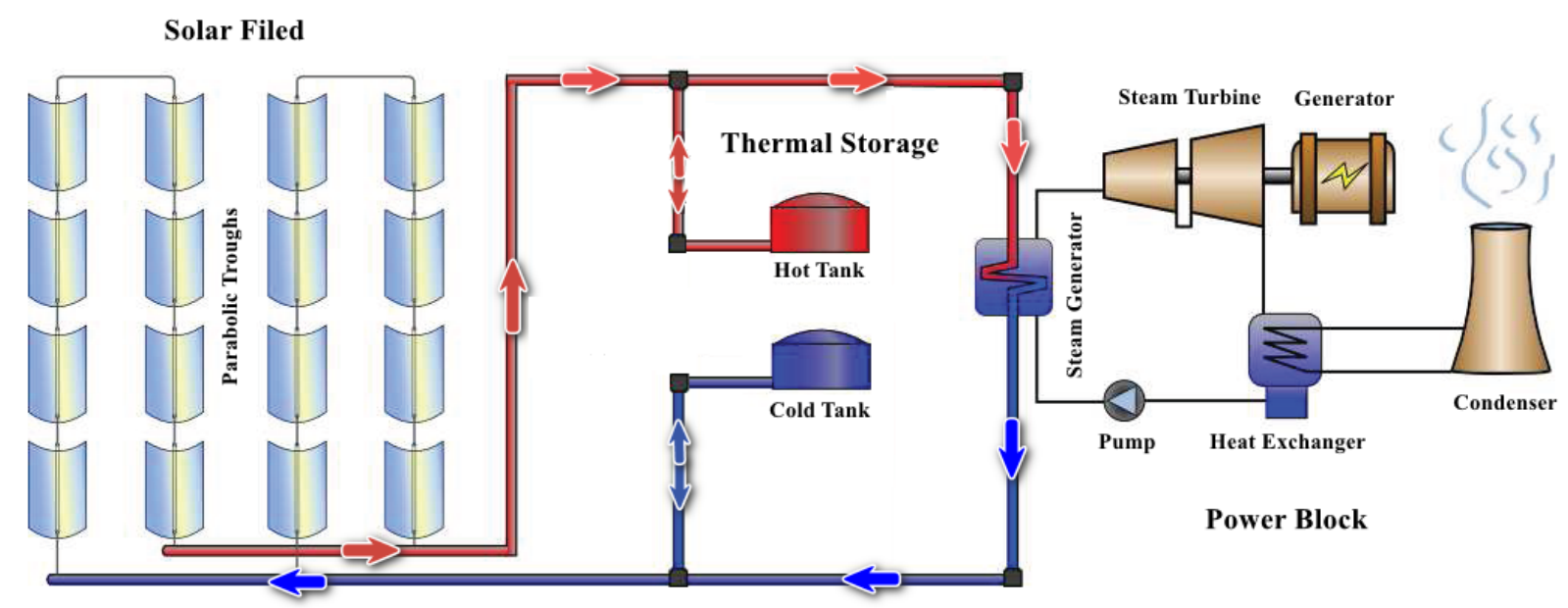

Figure (1) Schematic of PTSC power plant[16]

Figure 2 present a PTC sectional view. A glass envelope covers a metal tube (absorber tube). The space between the glass envelope and absorber is either vacuumed or filled with air in order to accommodate thermal expansion and to minimize convective heat losses. The absorber tube is coated with a selective surface that has a high solar absorption (>0.95 [17]) and a low thermal emittance to reduce radiative heat transfer loss. The length of the receiver is extended to 4 meters or above to minimize the effect of heat conduction. Finally, the absorber's diameter is reduced (82 times smaller [18]) in relation to the reflector width in order to reduce heat loss surface area. On the focal line of the collector axis, direct solar radiation is centered A single-axis monitoring system is included in the collector assembly to the aligned axis of the collector with the solar beam.

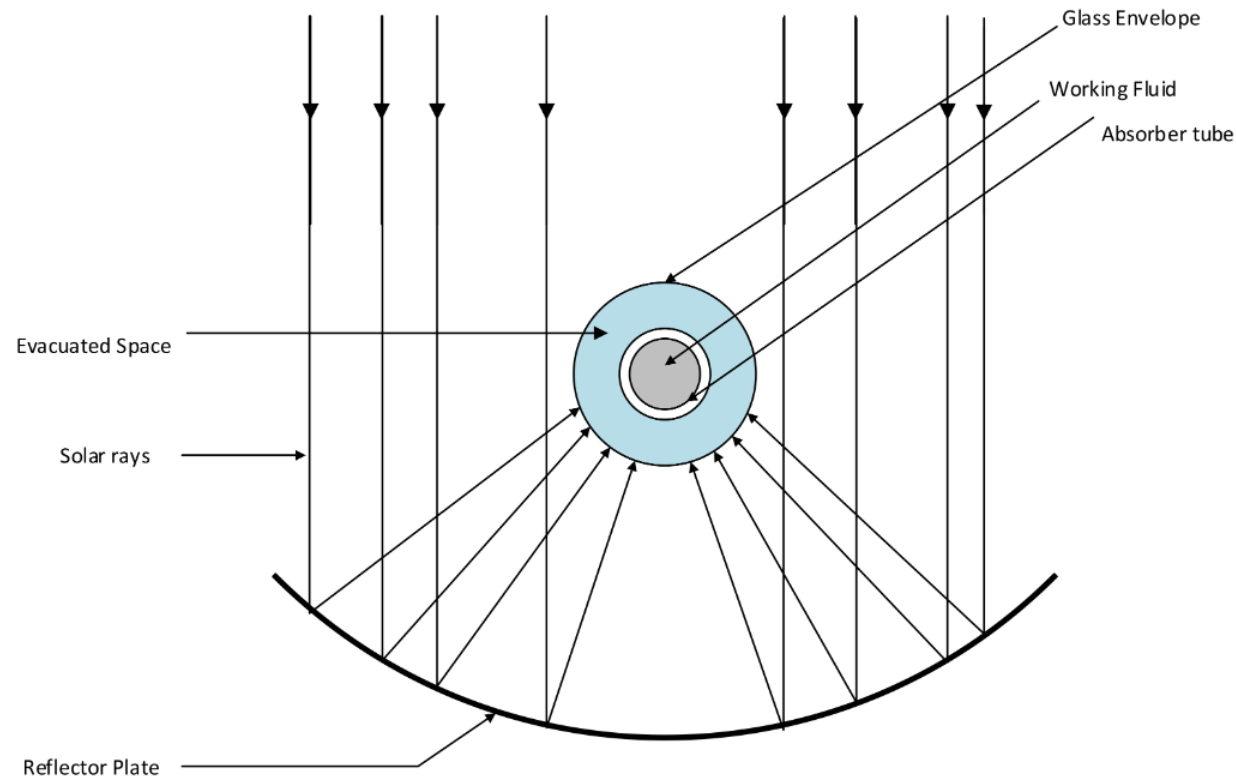

Figure (2) PTC sectional view [19] 
Parabolic trough collector PTC utilizes only the direct normal irradiance (DNI) portion of solar radiation. CSP projects based on Parabolic Troughs are extremely used in countries such as Spain and the United States, where medium to large-scale power generation is used. Among the power plants that use CSP technology the most commercially developed are PTC solar power plants [3]. Since they absorb more heat than flat plate collectors, parabolic trough collectors were chosen for the proposed plant configuration studied in the present work.

\subsection{Heat Transfer Fluid (HTF)}

Among the various forms of Heat Transfer Fluids, just molten salt and Therminaol VP-1 have a high level of performance for power plants. Due to the fact that molten salt as HTF has higher specific heat than other heat transfer fluids. Additionally, it has a high heat transfer capability, high density, and low viscosity fluid that flows smoothly through tubes and has excellent heat transfer properties. Table (1) summarizes the properties of the two HTF [20].

Table (1) Therminaol VP-1 and Molten Salt properties.

\begin{tabular}{lcccc}
\hline \hline HTF & $\begin{array}{c}\mathbf{T}_{\max } \\
{\left[{ }^{\circ} \mathbf{C}\right]}\end{array}$ & $\begin{array}{c}\mathbf{T}_{\min } \\
{\left[{ }^{\circ} \mathbf{C}\right]}\end{array}$ & $\begin{array}{c}\boldsymbol{\rho} \\
{\left[\mathbf{k g} / \mathbf{m}^{3}\right]}\end{array}$ & $\begin{array}{c}\mathbf{C}_{\mathbf{p}} \\
{\left[\mathbf{k J} / \mathbf{k g} .{ }^{\circ} \mathbf{C}\right]}\end{array}$ \\
\hline Therminol VP-1 & 398 & 12 & 1067 & 1.532 \\
Molten Salt & 593 & 238 & 1790 & 1.561 \\
\hline \hline
\end{tabular}

\section{Location selection and solar resource evaluation}

The location of the CSP plant is important for project developers and installers. Several considerations influence CSP site selection, encompassing everything from concerns about the environment to the fundamental requirement for electricity generation, such as solar power supply, supporting services, soil, water, connectivity, community considerations, and so on.

The method for selecting a site for the PTC power station is divided into two steps. (i) DNI value must be selected above $5 \mathrm{kWh} / \mathrm{m}^{2} /$ day to achieving high performance from the design system [21]. Alkuraymat annual DNI is extremely high (6.91 $\mathrm{kWh} / \mathrm{m}^{2} /$ day), based on DNI parameters and the limited availability of solar radiation data. (ii) The provision of utilities, such as water, soil, communication, and grid access, etc. Thus, this site meets all requirements for the installation of a CSP plant.

\section{Mathematical modeling and simulation}

In this section, the following equations are using to model the PTSC from the thermodynamic point of view. The absorbed solar radiation can be described as follows for PTSC [22] [23]:

$$
S=G_{b} \cdot \eta_{r}
$$

Where the beam irradiance is $G_{b}$ and the efficiency of the receiver is $\eta_{r}$ and obtained with the following equation: 


$$
\eta_{r}=\varrho_{c} \cdot \gamma \cdot \tau \cdot \alpha_{r} \cdot k_{\theta}
$$

where $\varrho_{c}$ is a mirror reflection coefficient, and the intercept factor is $\gamma, \tau$ is the glass cover transmittance, $\alpha_{r}$ is the receiver's absorption, and $k_{\theta}$ is an incidence angle modifier of the Euro-Trough collector and can be found by [24]:

$$
k_{\theta}=\cos (\theta)-5.2597 \times 10^{-4} \cdot \theta-2.85921 \times 10^{-5} \cdot \theta^{2}
$$

and the angle of incident $\theta$ is presented as follows [25]:

$$
\cos (\theta)=\sqrt{\cos ^{2}\left(\theta_{z}\right)+\cos ^{2}(\delta) \cdot \sin ^{2}(\omega)}
$$

From the above equation $\theta_{z}, \delta$, and $\omega$ are zenith angle, declination angle, and hour angle, respectively.

The thermal power generated from PTSC calculated from [25]:

$$
Q_{u}=A_{a p} \cdot F_{R} \cdot\left[S-\frac{A_{r}}{A_{a p}} \cdot U_{L} \cdot\left(T_{r, i}-T_{0}\right)\right]
$$

From the above equation, the collector aperture and receiver areas are $A_{a p}$ and $A_{r}$ respectively, the factor of the heat removal is $F_{R}$, the collector coefficient of overall heat loss is $U_{L}$, the temperatures inlet to the receiver and ambient are $T_{r, i}$ and $T_{0}$ respectively, the areas can be calculated as follows:

$$
\begin{gathered}
A_{a p}=\left[W-D_{c, o}\right] . L \\
A_{r}=\pi \cdot D_{r, o} \cdot L
\end{gathered}
$$

where is the collector width and length respectively are $W$ and $L$, and the outlet diameter of the cover and receiver are $D_{c, o}$ and $D_{r, o}$ respectively. Simply, we can calculate the heat removal factor by:

$$
F_{R}=\frac{m_{r} \cdot C_{p r}}{A_{r} \cdot U_{L}} \cdot\left[1-\exp \left(-\frac{A_{r} \cdot U_{L} \cdot F_{1}}{m_{r} \cdot C_{p r}}\right)\right]
$$

where $m_{r}$ is the receiver mass flow rate, $C_{p r}$ is the oil specific heat, and $F_{1}$ is the efficiency factor of the collector. The efficiency factor of the collector is defined as:

$$
F_{1}=\frac{U_{O}}{U_{L}}
$$

where the coefficient of collector overall heat transfer is $U_{O}$.

The coefficient of heat loss from the receiver to the surrounding is defined as three different forms of heat transfer coefficients, which are subsequently expressed.

The first form of heat loss is the heat transfer coefficient of convection between the cover and the surrounding can be determined by the following formula: 


$$
h_{c, c a}=\frac{N u_{a} \cdot k_{a}}{D_{c, o}}
$$

where the coefficient of the thermal air conductivity is $k_{a}$, and the Nusselt number is $N u_{a}$ and is presented as follows:

$$
N u_{a}=0.193 \cdot \operatorname{Re}^{0.618} \cdot \operatorname{Pr}^{0.33}
$$

where $R e$ is the Reynolds number, and $P r$ is the Prandtl number.

And the second coefficient of heat transfer is the coefficient of radiation between the cover and surrounding and is presented as follows:

$$
h_{r, c a}=\varepsilon_{c v} \cdot \sigma \cdot\left[T_{c}+T_{0}\right] .\left[T_{c}^{2}+T_{0}^{2}\right]
$$

where, $\varepsilon_{c v}$ is the cover emittance, $\sigma$ is the constant of Stefan Boltzmann, and $T_{c}$ is the average temperatures of cover.

The last type of heat loss is the coefficient of radiation from the absorber to the cover the which is presented as follows:

$$
h_{r, c r}=\frac{\sigma \cdot\left[T_{c}+T_{r, a v}\right] \cdot\left[T_{c}^{2}+T_{r, a v}^{2}\right]}{\frac{1}{\varepsilon_{r}}+\frac{A_{r}}{A_{c}} \cdot\left[\frac{1}{\varepsilon_{c v}}-1\right]}
$$

where $T_{r, a v}$ is the average temperature and $\varepsilon_{r}$ is the receiver emittance.

Hence, the coefficient of the overall heat loss of the collector is:

$$
U_{L}=\left[\frac{A_{r}}{\left(h_{c, c a}+h_{r, c a}\right) \cdot A_{c}}+\frac{1}{h_{r, c r}}\right]^{-1}
$$

where $A_{c}$ is the area of cover of the PTSC that is calculated as:

$$
A_{c}=\pi \cdot D_{c, o} \cdot L
$$

where $U_{O}$ for the parabolic trough collector is calculated as:

$$
U_{O}=\left[\frac{1}{U_{L}}+\frac{D_{r, o}}{h_{c, r, i} \cdot D_{r, i}}+\left(\frac{D_{r, o}}{2 . K_{r}} \ln \left(\frac{D_{r, o}}{D_{r, i}}\right)\right)\right]^{-1}
$$

Where $K_{r}$, and $D_{r, i}$, are the absorber coefficient of thermal conductivity, inlet diameter of the absorber, and $h_{c, r, i}$ is the heat transfer coefficient of convection inside the absorber which is calculated as:

$$
h_{c, r, i}=\frac{N u_{r} \cdot k_{r}}{D_{r, i}}
$$


The Nusselt number is expressed as follows:

$$
N u_{r}=\left\{\begin{array}{cc}
0.023 \cdot \operatorname{Re}^{0.8} \cdot \operatorname{Pr}^{0.4} & R e>2300 \\
4.364 & R e<2300
\end{array}\right.
$$

and we can be obtaining the average temperature of cover from:

$$
T_{c}=\frac{h_{r, c r} \cdot T_{r, a v}+\frac{A_{c}}{A_{r}} \cdot\left[h_{c, c a}+h_{r, c a}\right] \cdot T_{0}}{h_{r, c r}+\frac{A_{c}}{A_{r}} \cdot\left[h_{c, c a}+h_{r, c a}\right]}
$$

Thermal losses of the header pipes in the solar field are calculated by the following empirical equation [26]:

$$
\text { SfPipe } H l=0.01693 \Delta T-0.0001683 \Delta T^{2}+6.78 \times 10^{-7} \Delta T^{3}
$$

where $S$ f Pipe $H l$ is expressed per unit area of solar field aperture $\left[\mathrm{W} / \mathrm{m}^{2}\right]$, and $\Delta T$ $\left[{ }^{\circ} \mathrm{C}\right]$ is the difference between the average field temperature and the ambient air temperature:

$$
\Delta T=\frac{T_{\text {fieldoutlet }}+T_{\text {fieldinlet }}}{2}-T_{0}
$$

The ratio of solar field thermal energy $\left(\dot{Q}_{S f}\right)$ to input power block thermal energy $\left(\dot{Q}_{P B}\right)$ is known as the Solar Multiple.

$$
\text { Solar Multiple }=\frac{\dot{Q}_{S f}}{\dot{Q}_{P B}}
$$

The net output electric power block is obtained by multiplying the gross output electric power at the design point by the expected gross to the net conversion factor.

$$
\begin{aligned}
& \text { Estimated Net Output at Design }(\mathrm{MWe})=\text { Design Gross Output } \\
& (\mathrm{MWe}) \times \text { Estimated Gross to Net Conversion Factor }
\end{aligned}
$$

\subsection{Model validation}

System Advisor Model (SAM) is used for modeling and simulate the proposed PTC Solar power plant [14]. The software was validated by Price [15].

Figure 3 present the validation of the present model using the results from Archimede Plant [27]. Good agreement can be seen between the simulation results and the mentioned literature. The average error is $2.45 \%$, while at the time length $14 \mathrm{hr}$, the error raised to $15 \%$ due to the shutdown of the experimental plant. 


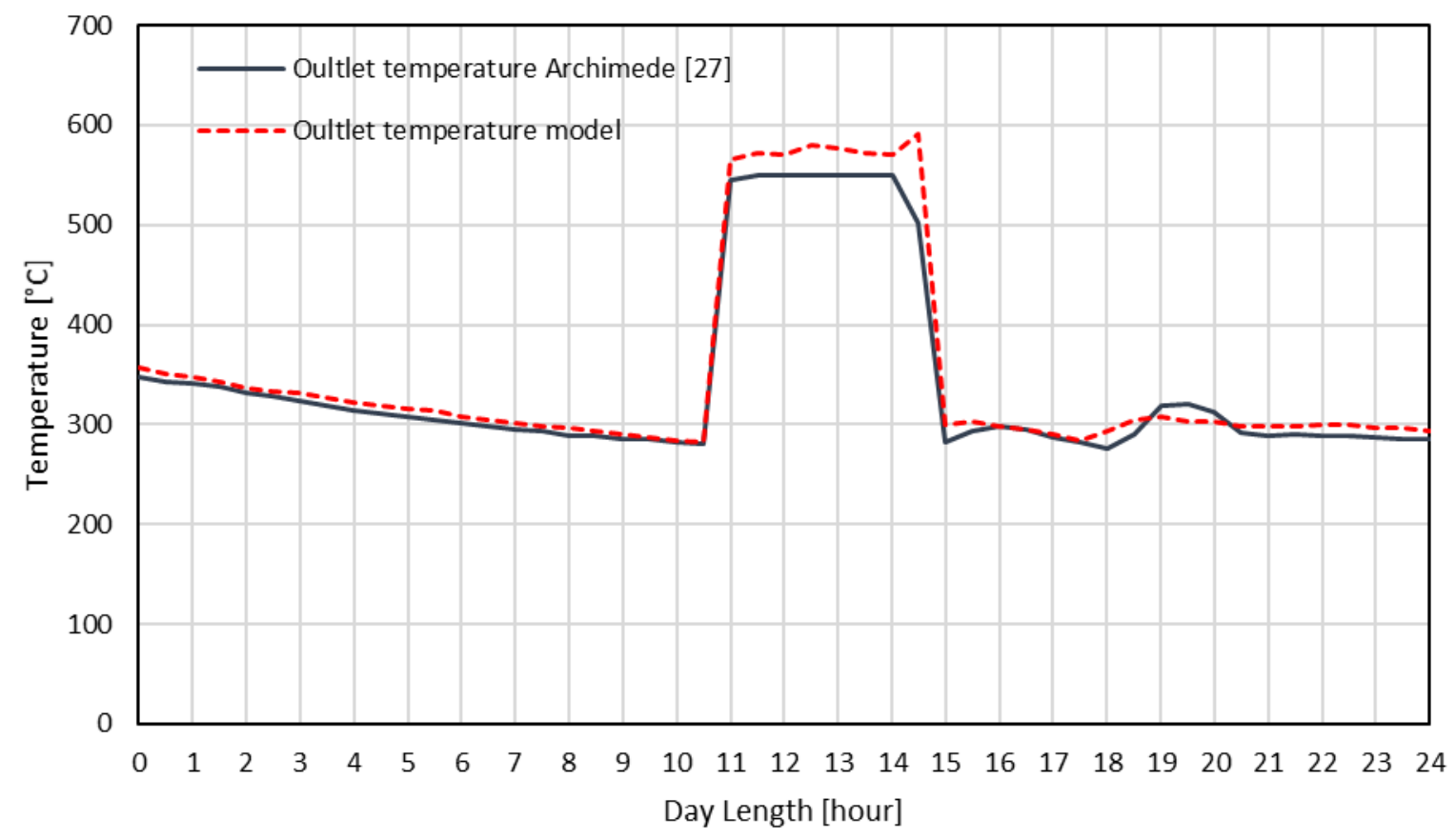

Figure (3) The model validation by comparing the outlet temperature of the current model and the experimental results of the Archimede plant [27].

The model is also verified using the data from M.J. Montes [24] by comparing the loop heat gain. Figure 4 demonstrates the comparison between the loop heat gain of the current model and the data from the mentioned literature, the error is $4.42 \%$.

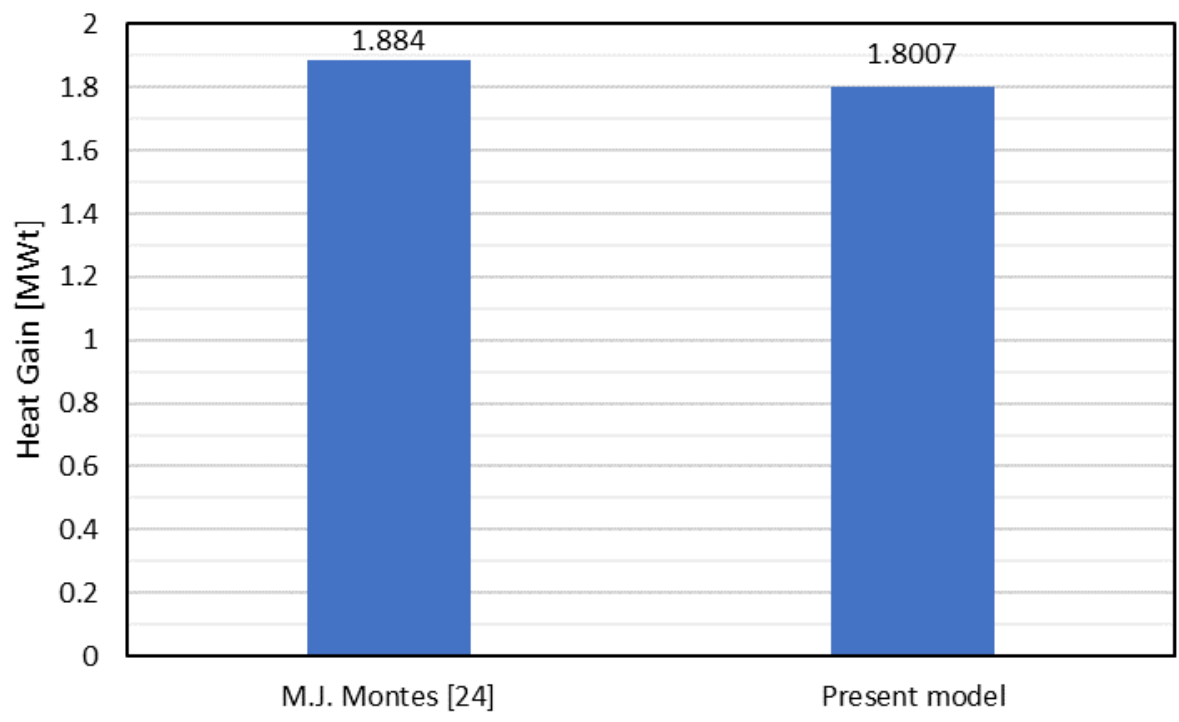

Figure (4) The model verification by comparing the loop heat gain of the current model and the data from M.J. Montes [24]. 


\subsection{Plant design parameters}

The plant characteristics listed below are used as inputs to SAM To evaluate the net generation of electricity, efficiency, capacity factor, and total thermal energies of the plant [14][28][29][30][31][32]. Table (2) shows these parameters.

Table (2) Design input parameters for the simulation.

\begin{tabular}{ll}
\hline Categories & Values \\
\hline Location and resources & \\
\hline Location & Alkuraymat, Egypt \\
Latitude and longitude & $29^{\circ} 16^{\prime} 43.00^{\prime \prime}$ North \\
& $31^{\circ} 14^{\prime} 56.00^{\prime \prime}$ East \\
\hline Solar Filed Parameters & 3 \\
\hline Solar Multiply & $894\left(\mathrm{w} / \mathrm{m}^{2}\right)$ \\
DNI at Design & $42^{\circ} \mathrm{C}$ \\
ambient temperature & $5 \mathrm{~m} / \mathrm{s}$ \\
wind velocity & 2 \\
Filed Subsections & $15 \mathrm{~m}$ \\
Row Spacing & $170^{\circ}$ \\
Stow Angle & $10^{\circ}$ \\
Deploy Angle & 0.85 \\
HTF Pump efficiency & $0.45 \mathrm{~W} / \mathrm{m}^{2}-\mathrm{k}$ \\
Piping thermal loss coefficient & $260^{\circ} \mathrm{C}$ \\
Freeze Protection Temperature & \\
\hline Heat transfer Fluid & $\mathrm{Hitec} \mathrm{Solar} \mathrm{Salt}$ \\
\hline HTF type & $293{ }^{\circ} \mathrm{C}$ \\
Loop inlet temperature & $550^{\circ} \mathrm{C}$ \\
Loop exit temperature & \\
\hline Collector (SCA) & Euro Trough ET150 \\
\hline Collector type & $817.5 \mathrm{~m}{ }^{2}$ \\
Aperture Area & $5.75 \mathrm{~m}$ \\
Aperture width & $150 \mathrm{~m}$ \\
collector assembly Length & 12 \\
modules per collector assembly & 2.11 \\
Average Surface to focus path length & $12.5 \mathrm{~m}$ \\
Length of the single module & $0.7 \mathrm{~L} / \mathrm{m}{ }^{2}$ \\
Water usage per wash & 63 \\
Washes per year & \\
\hline & \\
\hline Receiver & $0.067 \mathrm{~m}$ \\
\hline Receiver type & $0.07 \mathrm{~m}$ \\
Inner diameter of absorber tube & $0.122 \mathrm{~m}$ \\
Outer diameter of absorber tube & $0.125 \mathrm{~m}$ \\
Inner diameter of glass envelope & $166.25 \mathrm{~W} / \mathrm{m}$ \\
Receiver diameter of glass envelope & \\
\hline \hline & \\
\hline
\end{tabular}




\begin{tabular}{ll}
\hline Categories & Values \\
\hline Loop maximum flow rate & $12 \mathrm{~kg} / \mathrm{s}$ \\
Loop minimum flow velocity & $0.1 \mathrm{~m} / \mathrm{s}$ \\
Filed maximum flow velocity & $2 \mathrm{~m} / \mathrm{s}$ \\
filed Header minimum flow velocity & $2 \mathrm{~m} / \mathrm{s}$ \\
filed Header maximum flow velocity & $3 \mathrm{~m} / \mathrm{s}$ \\
\hline Design point & \\
\hline Loops number & 514 \\
Collectors per loop & 4 \\
Loop Aperture Area & $3270 \mathrm{~m}^{2}$ \\
Filed aperture area & $1,680,780 \mathrm{~m}^{2}$ \\
Total thermal power output & $1049.88 \mathrm{MWt}$ \\
Total land area & $1,517 \mathrm{Acres}$ \\
\hline Power block & \\
\hline Design gross output & $155 \mathrm{MWe}$ \\
Estimated gross to net conversation & 0.90 \\
Estimated net output at design & $140 \mathrm{MWe}$ \\
Rated cycle conversion efficiency & 0.443 \\
Design inlet temperature & $550^{\circ} \mathrm{C}$ \\
Design outlet temperature & $290^{\circ} \mathrm{C}$ \\
Boiler operating pressure & $150 \mathrm{bar}$ \\
Cooling condenser category & Evaporative \\
\hline Thermal energy storage & \\
\hline Storage hours & $16 \mathrm{hr}$. \\
Storage volume & $30869.6 \mathrm{~m}^{3}$ \\
\hline \hline
\end{tabular}

\section{Parabolic trough concentrated power plant performance analysis}

The plant is simulated for one year (from 0 to 8760 hours). A location with high direct normal irradiance and the standard metrological (TMY) data in the NREL database was used to simulate the theoretical CSP power plant to evaluate the plant efficiency. Alkuraymat receives a moderate amount of solar DNI with a range from 4.5 $\mathrm{kWh} / \mathrm{m}^{2} /$ day to $9 \mathrm{kWh} / \mathrm{m}^{2} /$ day. The economic feasibility of PTC power plant-based technologies requires that the DNI of the location exceed $1800 \mathrm{kWh} / \mathrm{m}^{2} /$ year $(5$ $\mathrm{kWh} / \mathrm{m}^{2} /$ day) [21]. Alkuraymat site receives an annual average DNI of $2,522.15$ $\mathrm{kWh} / \mathrm{m}^{2} /$ year $\left(6.91 \mathrm{kWh} / \mathrm{m}^{2} /\right.$ day $)$. DNI reaches a maximum of $9 \mathrm{kWh} / \mathrm{m}^{2} /$ day in June and a low of $4.5 \mathrm{kWh} / \mathrm{m}^{2} /$ day in January. Figure 5 illustrates the monthly difference in the average DNI at Alkuraymat. 


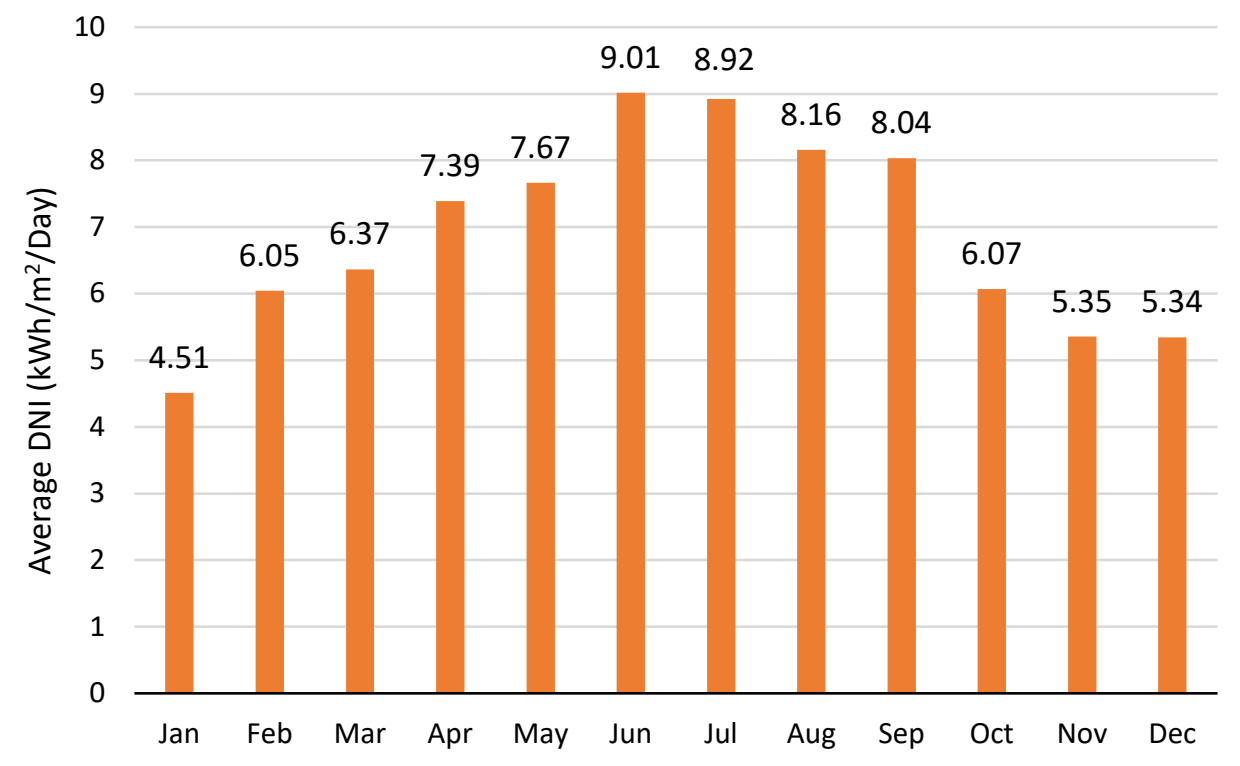

Figure (5) Monthly average DNI at Alkuraymat.

The maximum and minimum dry bulb temperatures were measured to be $41.92^{\circ} \mathrm{C}$ and $6.49^{\circ} \mathrm{C}$, respectively. The highest and lowest wind speeds were $11.3 \mathrm{~m} / \mathrm{s}$ and 0.2 $\mathrm{m} / \mathrm{s}$, respectively. Additionally, figure 6 illustrates the DNI $\left(\mathrm{W} / \mathrm{m}^{2}\right)$ heat map for the whole year.

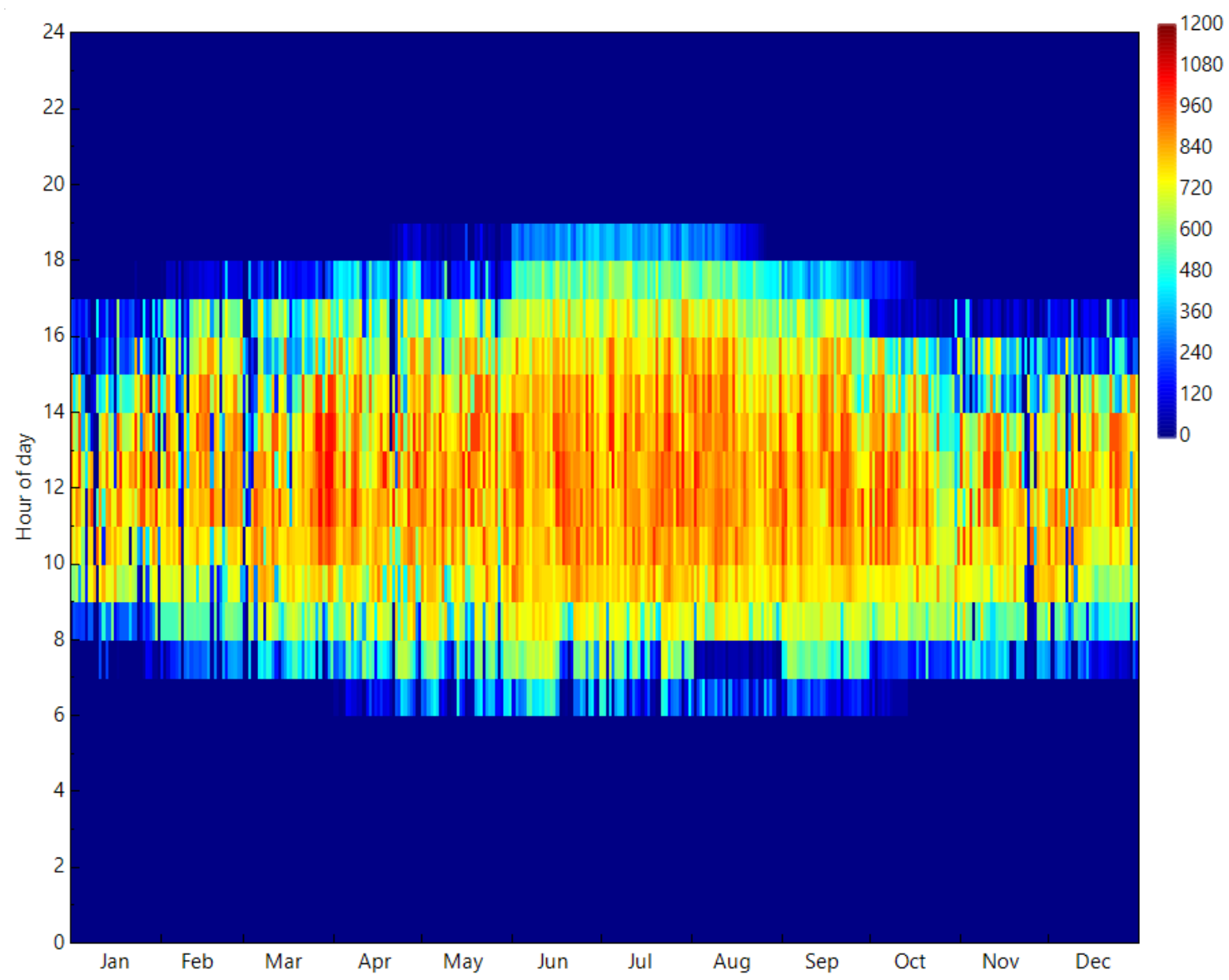

Figure (6) Direct normal irradiance (DNI) heat map (W/m²). 


\subsection{System performance}

Figure 7 illustrates the month-by-month energy output from the proposed PTC plant. The month of July produced the most energy $(110.84 \mathrm{GWh})$, while January generated the least energy $(25.78 \mathrm{GWh})$. As the HTF was circulated in a closed-loop, the cold header inlet's minimum temperature approached $251.2{ }^{\circ} \mathrm{C}$. Also, the hot header outlet's maximum temperature is $551.3^{\circ} \mathrm{C}$.

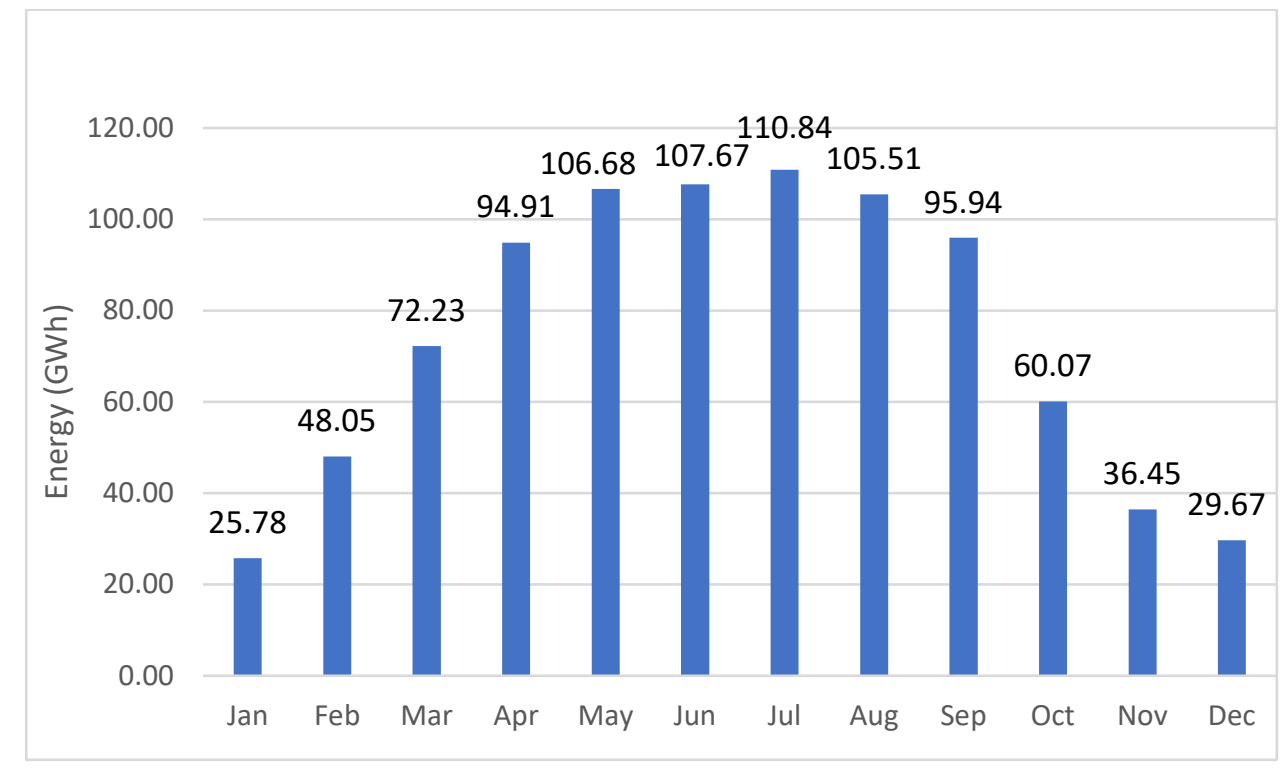

Figure (7) Energy generation Monthly.

The majority of Alkuraymat gets adequate sun rays for 10-14 hours a day during the year. It's worth remembering that power generation starts at 7.30 a.m., while the sun rises at $5.30 \mathrm{a}$ a.m. To ensure that the power plant starts properly, the hot tank should be held at a temperature of at least $300{ }^{\circ} \mathrm{C}$. To increase the tank temperature, an alternate fuel must be used.

Figure 8 shows the system performance parameter including gross electric power output, electric power to grid, thermal power input to power block, and thermal power incident for every month of the year. The month of June recorded the maximum thermal power from the solar field to the power block is $365.51 \mathrm{MWt}$, and the maximum gross and net electric power outputs from the power block are 177.1 and 173.1 MWe, respectively, as well as in July recorded the maximum filed thermal power incident as $1468.63 \mathrm{MWt}$. The PTCSP plant net output energy is summarized in table 3. 

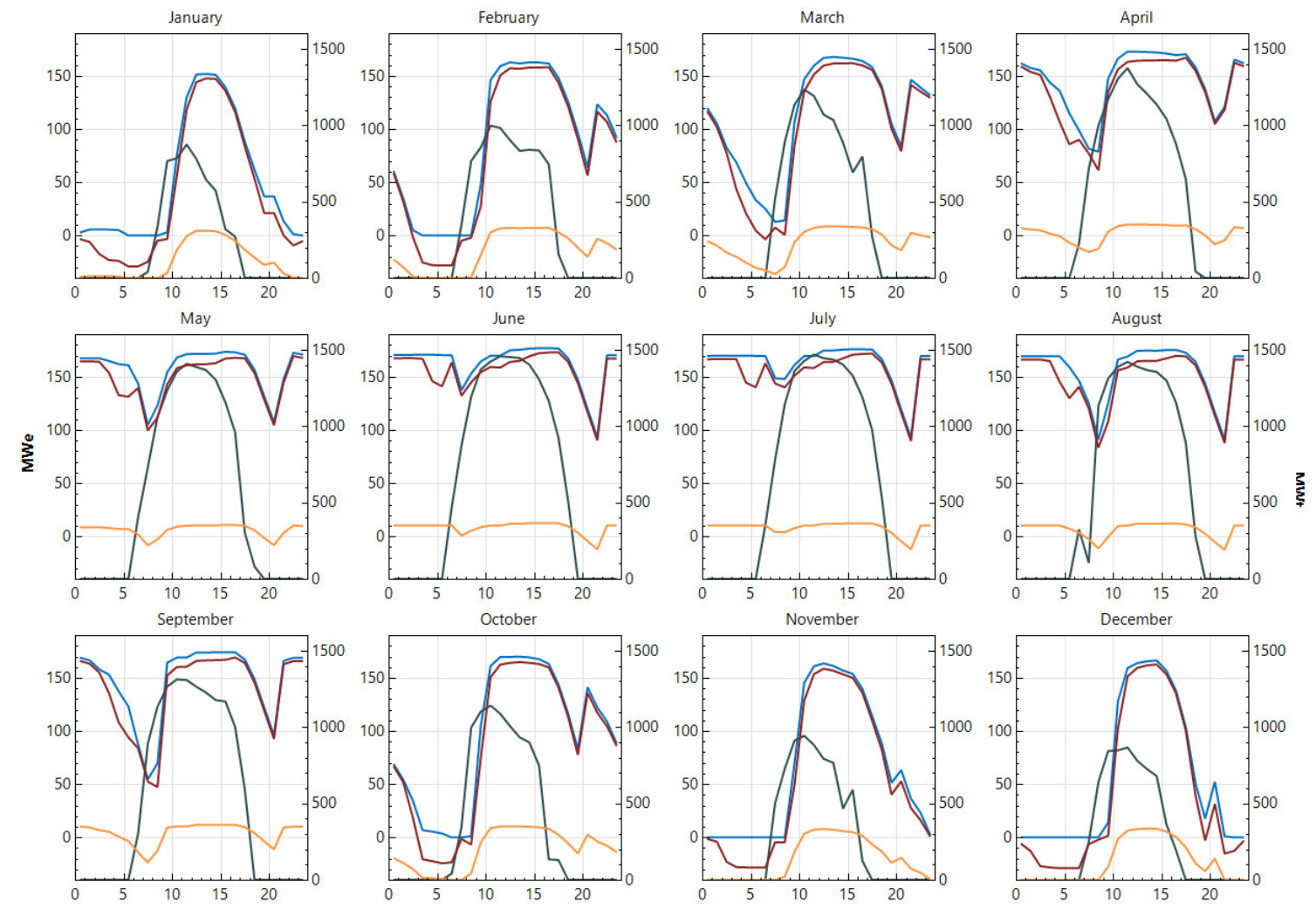

— Hourly Data: PC electrical power output: gross (MWe)

— Hourly Data: Field thermal power incident (MWt)

— Hourly Data: Total electric power to grid (MWe)

— Hourly Data: PC input energy (MWt)

Figure (8) Hourly data of cycle thermal power input, output(net), output (gross), and field thermal power incident.

Table (3) PTCSP plant Annual output energy.

\subsection{System optimization}

\begin{tabular}{lr}
\hline \hline Metric & \multicolumn{1}{c}{ Value } \\
\hline Net Energy & $893.82 \mathrm{GWh}$ \\
Gross to net conversion & $88 \%$ \\
Plant Capacity Factor & $73.1 \%$ \\
Water Usage & $2,184,329 \mathrm{~m}^{3}$ \\
Plant Efficiency & $19.4 \%$ \\
\hline
\end{tabular}

The optimization process aims to calculate the lowest $\mathrm{LCOE}$ value with the maximum annual energy production. The proposed design is optimized by means of two key design criteria, namely multiple solar and storage hours.

From figure 9, it can be concluded that the solar multiple of 3.4 and annual energy production of $985,335 \mathrm{GWh}$ of the CSP plant proposed in Alkuraymat meet a minimum value of 4.98 cents $/ \mathrm{kWh}$. As the solar multiple reaches 3.4 , the LCOE value and annual energy increase by a marginal amount. also, be noted that the LCOE value decreases rapidly before the solar multiple is raised to 3 and the cost reduction 
afterward is minimum. The optimal solar multiple for the proposed plant is suggested to be between 3.2 and 3.6 on the basis of a trade-off between LCOE and the generated annual energy.

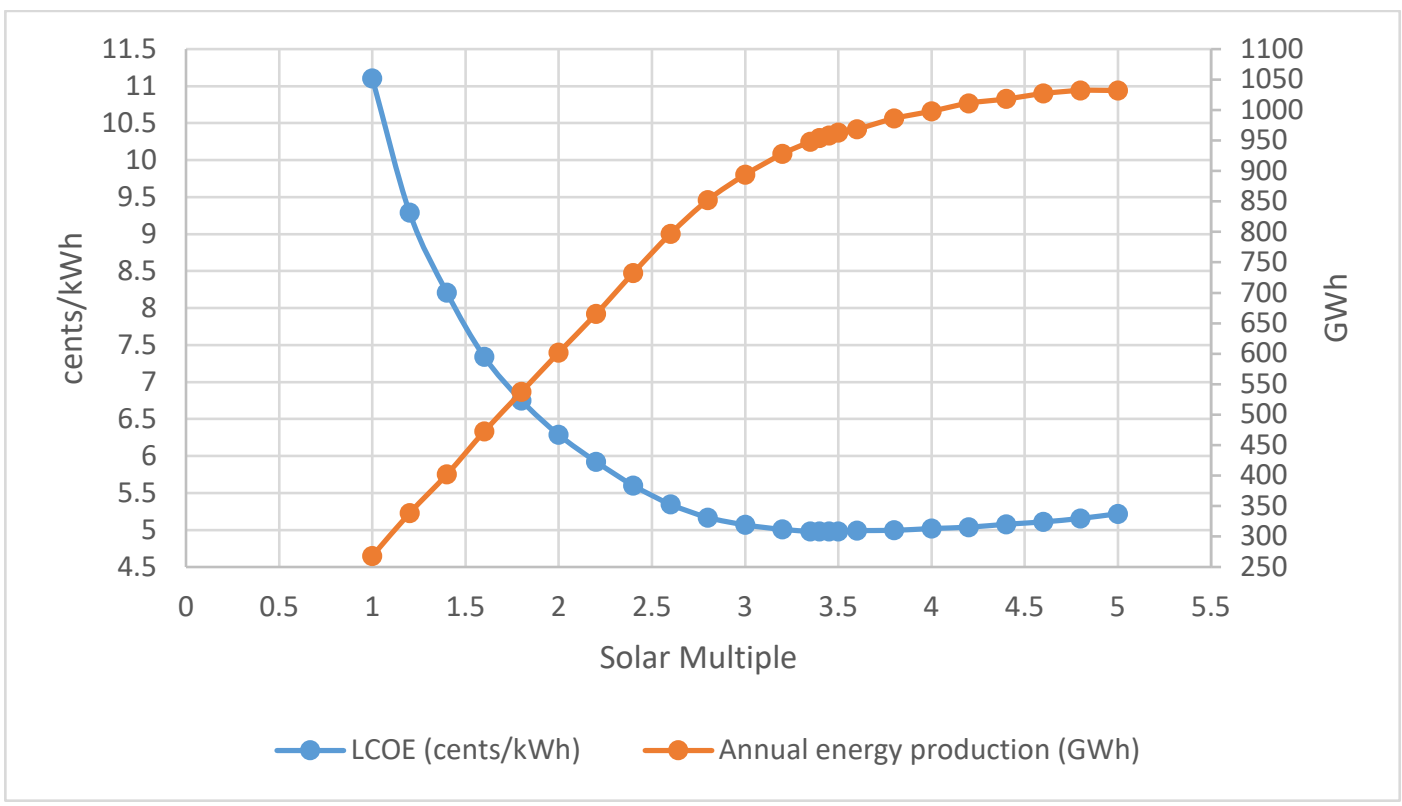

Figure (9) Annual energy production variation and LCOE with solar multiple.

The difference in annual energy produced and LCOE with maximum storage hours is illustrated in figure 10. According to figure 10, LCOE declines with a raise in TES full load hours before a certain value is reached, then it begins to rise again. The optimum value of storage hours is $12.5 \mathrm{~h}$ which meets the minimum value of LCOE of 4.79 cents $/ \mathrm{kWh}$, and the annual power generated of $943 \mathrm{GWh}$.

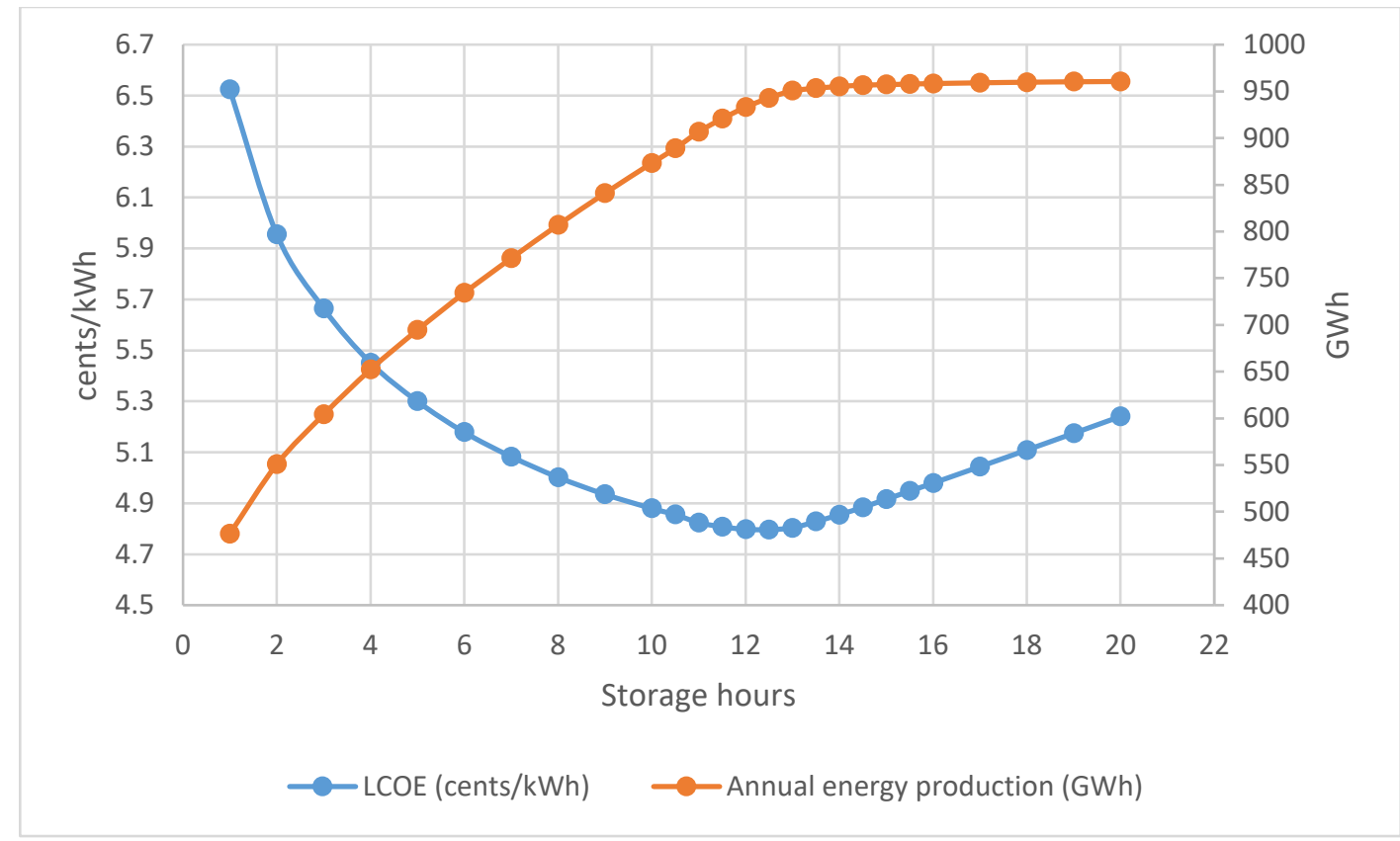

Figure (10) Annual energy production variation and LCOE with storage hours 
Table 4 Annual Energy yield comparison for the optimized CSP plant design

\begin{tabular}{lcc}
\hline \hline Metric & Initial & Optimized \\
\hline Annual Net Energy & $893.8 \mathrm{GWh}$ & $943.6 \mathrm{GWh}$ \\
Solar Multiple & 3 & 3.45 \\
Full load hour of TES & $16 \mathrm{~h}$ & $12.5 \mathrm{~h}$ \\
Gross to net conversion & $88 \%$ & $88 \%$ \\
Capacity Factor & $73.1 \%$ & $77.2 \%$ \\
Annual Water Usage & $2,184,329 \mathrm{~m}^{3}$ & $2,312,955 \mathrm{~m}^{3}$ \\
LCOE & 5.07 cents $/ \mathrm{kWh}$ & $4.79 \mathrm{cents} / \mathrm{kWh}$ \\
Plant Efficiency & $19.4 \%$ & $18.8 \%$ \\
\hline \hline
\end{tabular}

\subsubsection{Comparison of performance of PTC solar thermal power plant}

Table 5 compares the parabolic trough concentrated solar thermal power plant to previous research in the literature. From the comparison, the capacity factor of the plant is improved, and the efficiency of the plant is in the acceptable range. As well as the designed PTCSP plant in Alkuraymat, Egypt, is technically feasible and has a high potential for solar thermal energy generation.

Table (5) Comparison of PTCSP plant output with other literature.

\begin{tabular}{lrrrr}
\hline \multicolumn{1}{c}{ Author } & $\begin{array}{c}\text { Plant } \\
\text { Output } \\
\text { (nameplate) }\end{array}$ & $\begin{array}{c}\text { Annual } \\
\text { Energy } \\
\text { Production }\end{array}$ & $\begin{array}{c}\text { Mean } \\
\text { Plant } \\
\text { Efficiency }\end{array}$ & $\begin{array}{c}\text { Capacity } \\
\text { Factor }\end{array}$ \\
\hline Present work & $140 \mathrm{MWe}$ & $943.6 \mathrm{GWh}$ & $18.80 \%$ & $77.20 \%$ \\
R. P. Praveen et al. [19] & $100 \mathrm{MWe}$ & $392.6 \mathrm{GWh}$ & $14.74 \%$ & $44.90 \%$ \\
M. Abbas et al. [10] & $100 \mathrm{MWe}$ & $237 \mathrm{GWh}$ & $13.80 \%$ & $21.10 \%$ \\
Boukelia [29] & $50 \mathrm{MWe}$ & $114 \mathrm{GWh}$ & $21.77 \%$ & $38.20 \%$ \\
Boukelia [5] & $50 \mathrm{MWe}$ & $118.45 \mathrm{GWh}$ & $17.25 \%$ & $27.30 \%$ \\
\hline \hline
\end{tabular}

\section{Conclusions}

The design, performance analysis, and optimization has been carried out using SAM software for the Alkuraymat power station which consists of a 140MW parabolic power plant integrated with thermal energy storage. The key concluded remarks could be summarized as follows:

- The annual average DNI is $6.91 \mathrm{kWh} / \mathrm{m}^{2} /$ day and the annual energy production yield of $893.82 \mathrm{GWh}$ for initial analysis of the plant, as well as the plant efficiency, is $19.40 \%$.

- Based on the results of the system optimization, the solar multiple is 3.45 and the storage hours are $12.5 \mathrm{~h}$.

- Annual energy production may be raised to $943.6 \mathrm{GWh}$ with a corresponding drop in LCOE to 4.79 cents $/ \mathrm{kWh}$, according to the study of the optimal design.

\section{References}

[1] NREL, "ISCC Kuraymat," Concentrating Solar Power Projects, 2013. [Online]. Available: https://solarpaces.nrel.gov/iscc-kuraymat.

[2] A. B. Awan, M. Zubair, R. P. Praveen, and A. R. Bhatti, "Design and comparative analysis of photovoltaic and parabolic trough based CSP plants," Sol. Energy, vol. 183, no. December 2018, pp. 551-565, 2019.

[3] A. Bilal Awan, M. N. Khan, M. Zubair, and E. Bellos, "Commercial parabolic 
trough CSP plants: Research trends and technological advancements," Sol. Energy, vol. 211, pp. 1422-1458, Nov. 2020.

[4] T. eddine Boukelia and M.-S. Mecibah, "Parabolic trough solar thermal power plant: Potential, and projects development in Algeria," Renew. Sustain. Energy Rev., vol. 21, pp. 288-297, May 2013.

[5] T. E. Boukelia, M. S. Mecibah, B. N. Kumar, and K. S. Reddy, “Optimization, selection and feasibility study of solar parabolic trough power plants for Algerian conditions," Energy Convers. Manag., vol. 101, pp. 450-459, Sep. 2015.

[6] I. Llorente García, J. L. Álvarez, and D. Blanco, "Performance model for parabolic trough solar thermal power plants with thermal storage: Comparison to operating plant data," Sol. Energy, vol. 85, no. 10, pp. 2443-2460, 2011.

[7] M. J. Montes, A. Abánades, and J. M. Martínez-Val, "Performance of a direct steam generation solar thermal power plant for electricity production as a function of the solar multiple," Sol. Energy, vol. 83, no. 5, pp. 679-689, May 2009.

[8] T. Larraín, R. Escobar, and J. Vergara, "Performance model to assist solar thermal power plant siting in northern Chile based on backup fuel consumption," Renew. Energy, vol. 35, no. 8, pp. 1632-1643, Aug. 2010.

[9] S. A. Kalogirou, "Solar thermoelectric power generation in Cyprus: Selection of the best system," Renew. Energy, vol. 49, pp. 278-281, Jan. 2013.

[10] M. Abbas, Z. Belgroun, H. Aburidah, and N. K. Merzouk, "Assessment of a Solar Parabolic Trough Power Plant for Electricity Generation under Mediterranean and Arid Climate Conditions in Algeria," Energy Procedia, vol. 42, pp. 93-102, 2013.

[11] T. Ruegamer et al., "Molten salt for parabolic trough applications: System simulation and scale effects," Energy Procedia, vol. 49, no. 0, pp. 1523-1532, 2014.

[12] C. Xu, Z. Wang, X. Li, and F. Sun, "Energy and exergy analysis of solar power tower plants," Appl. Therm. Eng., vol. 31, no. 17-18, pp. 3904-3913, Dec. 2011.

[13] V. S. Reddy, S. C. Kaushik, and S. K. Tyagi, "Exergetic analysis and performance evaluation of parabolic trough concentrating solar thermal power plant (PTCSTPP)," Energy, vol. 39, no. 1, pp. 258-273, Mar. 2012.

[14] "System Advisor Model (SAM)." [Online]. Available: https://sam.nrel.gov/.

[15] H. Price, "A Parabolic Trough Solar Power Plant Simulation Model," in Solar Energy, 2003, pp. 665-673.

[16] M. J. Wagner, P. Gilman, M. J. Wagner, and P. Gilman, "Technical Manual for the SAM Physical Trough Model," Contract Des., no. June, 2011.

[17] V. Poghosyan and M. I. Hassan, "Techno-economic assessment of substituting natural gas based heater with thermal energy storage system in parabolic trough concentrated solar power plant," Renew. Energy, vol. 75, pp. 152-164, Mar. 2015.

[18] V. K. Jebasingh and G. M. J. Herbert, "A review of solar parabolic trough 
collector," Renew. Sustain. Energy Rev., vol. 54, pp. 1085-1091, Feb. 2016.

[19] M. R. P., Praveen; Abdul Baseer, Mohammad; Awan, Ahmed B.; Zubair, "Performance Analysis and Optimization of a Parabolic Trough Solar Power Plant in the Middle East Region," Energies, vol. 11, no. 4, p. 741, Mar. 2018.

[20] M. Ashouri, F. Razi Astaraei, R. Ghasempour, M. H. Ahmadi, and M. Feidt, "Thermodynamic and economic evaluation of a small-scale organic Rankine cycle integrated with a concentrating solar collector," Int. J. Low-Carbon Technol., p. ctv025, Aug. 2015.

[21] K. Kaygusuz, "Prospect of concentrating solar power in Turkey: The sustainable future," Renew. Sustain. Energy Rev., vol. 15, no. 1, pp. 808-814, Jan. 2011.

[22] E. Bellos and C. Tzivanidis, "A detailed exergetic analysis of parabolic trough collectors," Energy Convers. Manag., vol. 149, pp. 275-292, Oct. 2017.

[23] M. A. Haghghi, S. M. Pesteei, A. Chitsaz, and J. Hosseinpour, "Thermodynamic investigation of a new combined cooling, heating, and power (CCHP) system driven by parabolic trough solar collectors (PTSCs): A case study," Appl. Therm. Eng., vol. 163, no. September, 2019.

[24] M. J. Montes, A. Abánades, J. M. Martínez-Val, and M. Valdés, "Solar multiple optimization for a solar-only thermal power plant, using oil as heat transfer fluid in the parabolic trough collectors," Sol. Energy, vol. 83, no. 12, pp. 2165-2176, Dec. 2009.

[25] J. A. Duffie (Deceased), W. A. Beckman, and N. Blair, Solar Engineering of Thermal Processes, Photovoltaics and Wind. 2020.

[26] A. M. Patnode, S. A. Klein, and D. T. Reindl, "Simulation and performance evaluation of parabolic trough solar power systems," Am. Sol. Energy Soc. Sol. 2006 35th ASES Annu. Conf., 31 st ASES Natl. Passiv. Sol. Conf., 1st ASES Policy Mark. Conf., ASME Sol. Energy Div. Int. Sol. Energy Conf., vol. 1, pp. 176-181, 2006.

[27] A. Maccari et al., "Archimede Solar Energy Molten Salt Parabolic Trough Demo Plant: A Step Ahead towards the New Frontiers of CSP," Energy Procedia, vol. 69, pp. 1643-1651, May 2015.

[28] Coastal, "HITEC ® Heat Transfer Salt," Coast. Chem. Co., 2009.

[29] T. E. Boukelia, M. S. Mecibah, B. N. Kumar, and K. S. Reddy, "Investigation of solar parabolic trough power plants with and without integrated TES (thermal energy storage) and FBS (fuel backup system) using thermic oil and solar salt," Energy, vol. 88, pp. 292-303, Aug. 2015.

[30] W. A. K. Al-Maliki, F. Alobaid, V. Kez, and B. Epple, "Modelling and dynamic simulation of a parabolic trough power plant," J. Process Control, vol. 39, pp. 123-138, Mar. 2016.

[31] P. H. Wagner and M. Wittmann, "Influence of Different Operation Strategies on Transient Solar Thermal Power Plant Simulation Models with Molten Salt as Heat Transfer Fluid," Energy Procedia, vol. 49, pp. 1652-1663, 2014.

[32] Archimede Solar Energy, "HCEMS11 - Technical Data." 2016. 